\title{
Relationship Between Agility Performance and Cognitive Parameters of Female Basketball Players
}

\author{
Ismail Gokhan \\ School of Physical Education and Sports, Harran University, Sanliurfa, Turkey \\ Tel: 90-544-604-6369 E-mail: is_gokhan@hotmail.com \\ Yakup Aktas (Corresponding author) \\ School of Physical Education and Sports, Harran University, Sanliurfa, Turkey \\ Tel: 90-505-855-2107Ｅ-mail: yakupaktas@harran.edu.tr
}

Received: August 19, 2019 Accepted: September 20, 2019

Published: September 24, 2019

doi:10.5296/jei.v5i2.15301 URL: https://doi.org/10.5296/jei.v5i2.15301

\begin{abstract}
Objective: This study aims at investigating the relationship between agility performance and perception and decision-making mechanisms of female basketball players.

Materials and Methods: A total of seventeen elite female basketball player playing in Second League in Turkey Basketball Federation participated in this study voluntarily. The mean age of the participants was $21.53 \pm 2.47$ (years), the mean height was $175.67 \pm 5.36(\mathrm{~cm})$ and the mean body weight was $66.80 \pm 7.76(\mathrm{~kg})$. Agility performance of the participants was measured by Newtest Powertimer 300, and perceptual and decision-making parameters were measured by Psychotechnic Vienna test system. Since the number of participants was less than thirty, Spearman Correlation test was applied.
\end{abstract}

Findings: The average perception and decision making parameters of female basketball players were as follows: Visual Perception Test (VPT): 46.82 \pm 2.65 , Reasoning Test (RT): 88.58 \pm 9.43 , Response Quality and Speed Test (RQST) number of correct answers: 243.76 \pm 14.14 , RQST time: $0.78 \pm 0.06$, Speed and Distance Estimation Test (SDET): 45.00 \pm 2.76 , Dual-Process Skill and Angle of View Test (DPS-AVT) viewing angle: 99.58 \pm 7.72, DPS-AVT collision number of cars: $3.76 \pm 2.13$ and the number of collisions of DPS-AVT road sides: $3.23 \pm 2.01$ (Table 1). When the correlation between agility performance (total time) and RQST time and SDET parameters was examined, a negative linear 
relationship was found $(\mathrm{r}=0.842 / \mathrm{r}=0.827, \mathrm{p}<0.01)$. However, agility performance (total time) and VPT, RT, RQST number of correct answers, DPS-AVT viewing angle, DPS-AVT car crash number, DPS-AVT roadsides collision parameters were not statistically significant $(\mathrm{p}>0.05)$.

As a result, in training contents, preference of visual stimuli, reaction and prediction studies will be important for improving agility. Furthermore, it is thought that cognitive parameters should be taken into consideration in the selection and orientation of athletes.

Keywords: Basketball, Agility, Cognitive, Psychotechnic

\section{Introduction}

In a basketball competition, the athletes cover a distance by jumping, directional running and sprinting. When considered in terms of energy metabolism, aerobic and anaerobic systems are used in this process, which they pass through very fast and violent movements, and it is stated that the predominant system is anaerobic system (Usgu, 2016). When the basketball branch is examined in terms of the content of the game, it is seen that it has important personality traits such as desire to fight, courage, integrity, cooperation, accuracy and self-confidence. When the basketball branch is considered with many important features, it is seen that it is an indispensable sport for children, adolescents and adults (Nalbant, 2013).

Although the branch of basketball is seen as a sport where anaerobic capacity is not in the foreground in terms of playing time, it is seen that anaerobic activities requiring explosive force (such as splash) are more dominant when the contents of movement in the game are examined. In many literature information, it is stated that movements such as jumping and sudden displacement in basketball game affect the performance of the players. However, it is also known that high intensity activities in basketball games require good strength, speed and agility (Stojanovic et al., 2012; Delextrat \& Cohen, 2008; Castagna et al., 2007; Padulo et al., 2016).

Agility is generally defined as the effective combination of sudden stop, change of direction and acceleration while body maintains its motor control in the vertical or horizontal direction (Verstegen, 2001). When we look at another definition of agility, it is stated that agility is the control and coordination ability that enables the body to be in the right position during very rapid shifts over a series of movements (Twist \& Benicky, 1995). It is also reported that the components of agility are psychological and physical factors such as decision-making mechanisms and the speed of direction change (Sheppard \& Young, 2006).

Since basketball competitions are played very fast and against time, it causes great stress on players. Considering this aspect, due to the nature of basketball, the psychological factors of the competition create considerable stress. In order to be successful in such fast-paced competitions, it is extremely important for athletes to make the right decisions quickly to play as accurately as possible.

\section{Method}

A total of 17 female basketball player playing in Second League in Turkey Basketball 
Federation participated in this study voluntarily. The mean age of the participants was $21.53 \pm 2.47$ (years), the mean height was $175.67 \pm 5.36(\mathrm{~cm})$ and mean body weight was $66.80 \pm 7.76(\mathrm{~kg})$.

\subsection{Agility Test}

In order to determine the agility performance of the participants, Newtest Powertimer 300 (Newtest, Finland) device that measures with the type of 1/1000 sec. was used.

Right photocell gate was placed to 5 metres right side of mat, left photocell gate was placed to 5 metres left side of the mat, and the initial photocell gate was placed to 5 metres behind of the mat. After 5 meters of running, the system decided randomly which way the participants would run.

\subsection{Cognitive Measurements}

Psychotechnical Vienna test was used to determine the cognitive skills of the participants such as visual screening, state information, model recognition, and estimation.

\subsubsection{Visual Perception Test (VPT)}

Visual perception performance and perceptual velocity were measured after images related to the photograph shown for short periods (1 second).

\subsubsection{Reasoning Test (RT)}

This test, which is based on understanding and recognizing the relationships between abstract visual shapes, measured the reasoning ability of individuals.

\subsubsection{Response Quality and Speed Test (RQST)}

In this test, which measures Intense Stimulus Flow and Response Rate and Quality under stress, the correct responses and speeds of the responses to visual stimuli of different colors and audible stimuli of different tones were measured.

\subsubsection{Speed and Distance Estimation Test (SDET)}

In this test, the candidate's ability to estimate the speed of motion of stimuli and the distance between stimuli was measured. At the same time, one's ability to estimate moving velocities and distance of objects in motion was measured.

\subsubsection{Dual-Process Skill and Angle of View Test (DPS-AVT)}

Participants' dual-process skill, peripheral vision skill and when the stimulus given from the right and left extremities of the head at angles of 120 and 140 degrees come into view of the person was studied.

\subsection{Statistical Analysis}

SPSS 16 package program was used in the analysis of the data obtained from the study. The suitability of the data for normal distribution was tested and Spearman correlation test was used to examine the relationship between the parameters. Significance level was determined 
as 0.05 and 0.01 .

\section{Results}

The mean age of the participants was $21.53 \pm 2.47$ (years), mean height was $175.67 \pm 5.36(\mathrm{~cm})$ and mean body weight was $66.80 \pm 7.76(\mathrm{~kg})$. Mean and perception parameters of the participants were as follows: VPT: $46.82 \pm 2.65$, RT: $88.58 \pm 9.43$, RQST number of correct answers: $243.76 \pm 14.14$, RQST time: $0.78 \pm 0.06$, SDET: $45.00 \pm 2.76$, DPS-AVT viewing angle: $99.58 \pm 7.72$, DPS-AVT collision number of the car: $3.76 \pm 2.13$ and the number of collisions of DPS-AVT road sides: $3.23 \pm 2.01$ (Table 1). When the correlation between agility performance (total time) and RQST time and SDET parameters was examined, a negative linear relationship was found $(\mathrm{r}=0.842 / \mathrm{r}=0.827, \mathrm{p}<0.01)$. However, agility performance (total time) and VPT, RT, RQST number of correct answers, DPS-AVT angle of view, DPS-AVT car crash number, DPS-AVT collisions of road sides parameters were not statistically significant $(\mathrm{p}>0.05)$ (Table 1).

Table 1. Relationship between agility performance and cognitive parameter values

\begin{tabular}{|c|c|c|c|}
\hline Parameters $(n=14)$ & $\mathbf{X X} / \mathbf{S S}$ & Values & Agility (ms) \\
\hline \multirow{2}{*}{ VPT } & \multirow{2}{*}{$46.82 \pm 2.65$} & $\mathrm{r}$ & -.219 \\
\hline & & $\mathrm{p}$ & .399 \\
\hline \multirow{2}{*}{ RT } & \multirow{2}{*}{$88.58 \pm 9.43$} & $\mathrm{r}$ & .375 \\
\hline & & $\mathrm{p}$ & .138 \\
\hline \multirow{2}{*}{ RQST Number of Correct Answers } & \multirow{2}{*}{$243.76 \pm 14.14$} & $\mathrm{r}$ & .367 \\
\hline & & $\mathrm{P}$ & .147 \\
\hline \multirow{2}{*}{ RQST Time (second) } & \multirow{2}{*}{$0.78 \pm 0.06$} & $\mathrm{r}$ & -.842 \\
\hline & & $P$ & $.000 * *$ \\
\hline \multirow{2}{*}{ SDET } & \multirow{2}{*}{$45.00 \pm 2.76$} & $\mathrm{r}$ & -.827 \\
\hline & & $\mathrm{p}$ & $.000 * *$ \\
\hline \multirow{2}{*}{ DPS-AVT Angle of View } & \multirow{2}{*}{$99.58 \pm 7.72$} & $\mathrm{r}$ & .307 \\
\hline & & $\mathrm{p}$ & .230 \\
\hline \multirow{2}{*}{ DPS-AVT Number of Collisions of Cars } & \multirow{2}{*}{$3.76 \pm 2.13$} & $\mathrm{r}$ & .341 \\
\hline & & $\mathrm{p}$ & .181 \\
\hline \multirow{2}{*}{ DPS-AVT Roadside Collisions } & \multirow{2}{*}{$3.23 \pm 2.01$} & $\mathrm{r}$ & -.167 \\
\hline & & $\mathrm{p}$ & .523 \\
\hline
\end{tabular}

Note. $* \mathrm{p}<0.05, * * \mathrm{p}<0.01$. 


\section{Discussion}

In our study, when the correlation between female basketball players' agility performance (total time) and RQST time and SDET parameters was examined, it was found to be a negative linear relationship $(\mathrm{r}=0.842 / \mathrm{r}=0.827, \mathrm{p}<0.01)$. However, agility performance (total time) and VPT, RT, RQST number of correct answers, DPS-AVT viewing angle, DPS-AVT number of car collisions, DPS-AVT roadside collision parameters were not statistically significant $(\mathrm{p}>0.05)$ (Table 1$)$.

When the literature is examined, there are some studies on agility, perception and decision-making parameters. When looked at the studies, there are many studies investigating the components of agility affecting the direction of change.

According to Chaouachi et al. (2009), findings obtained on agility should be seen as a major physiological ability in male elite basketball players. In their studies, Çömük and Erden (2010) determined a relationship between agility performance and reaction times of elite female figure skaters at the ages of 16-23 and in their studies participated by 15 rugby players (2011), Serpell et al. discussed the perceptual and decision-making components of agility and they found the perception and response time pre-test and post-test values of the experimental group $(n=8)$ statistically significant when compared to the control group $(n=7)$. These studies support our research.

The sportive performance of a successful team depends on its superior predictive and decision-making skills as well as its well-developed physical characteristics (Abemathy, 1999). In decision-making situations, response quality is crucial to the success of the team (Romeas, 2015). Accurate and well-timed decision-making is crucial for the performance of elite athletes (Roca et al., 2011).

As a result, the use of visual stimuli to improve the performance of agility training in organizing training content in fast sports such as basketball can increase athletes' perception of the competition and correct decision values. It is thought that perception, pre-thesis and training should be given in all sports trainings.

\section{References}

Abemathy, B., Wood, M. J., \& Parks, S. (1999). Can the Anticipatory Skills of An Expert be Learned by Novices? Research Quarterly for Exercise and Sport, 70, 326-345. https://doi.org/ 10.1080/02701367.1999.10608050

Castagna, C., Manzi, V., D’ottavio, S., Annino, G., Padua, E., \& Bishop, D. (2007). Relation Between Maximal Aerobic Power and The Ability to Repeat Sprints in Young Basketball Players. The Journal of Strength and Conditioning Research, 21(4), 1172. https://doi.org/ 10.1519/R-20376.1

Chaouachi, A., Brughelli, M., Chamari, K., Levin, G. T., Abdelkrim, B. N., Laurencelle, L., \& Castagna, C. (2009). Lower limb maximal dynamic strength and agility determinants in elite basketball players. J. Strength Cond Res., 23(5), 1570-7. https://doi.org/10.1519/JSC.0b013e 3181a4e7f0 


\section{I Macrothink}

Çömük, N., \& Erden, Z. (2010). Artistik Buz Pateninde Üçlü Sıçrayış Performansının Çeviklik ve Reaksiyon Zamanı ile İlişkisi. Fizyoterapi Rehabilitasyon, 21(2), 75-80.

Delextrat, A., \& Cohen, D. (2008). Physiological Testing of Basketball Players: Toward A Standard Evaluation of Anaerobic Fitness. The Journal of Strength and Conditioning Research, 22, 1066-1072. https://doi.org/10.1519/JSC.0b013e3181739d9b

Nalbant, Ö. (2013). Basketbol, Farklı Bakış Açılarıly Bilindik ve Bilinmedik Yönleriyle. Nobel Yayınevi.

Padulo, J., Bragazzi, N. L., Nikolaidis, P. T., Iacono, A. D., Attene, G., Pizzolato, F., ... Migliaccio, G. M. (2016). Repeated Sprint Ability in Young Basketball Players: Multi-Direction vs. One-Change of Direction (Part 1). Frontiers in Physiology, 7, 133. https://doi.org/10.3389/fphys.2016.00133

Roca, A., Ford, P., McRobert, A., \& Williams, A. M. (2011). Identifying the Processes Underpinning Anticipation and Decision-Making in a Dynamic Time-Constrained Task. Cognitive Processing, 12(3), 301-310. https://doi.org/10.1007/s10339-011-0392-1

Romeas, T., Guldner, A., \& Faubert, J. (2015). 3D-Multiple Object Tracking training task improves passing decision-making accuracy in soccer players. Psychology of Sport \& Exercise, 22, 1-9. https://doi.org/10.1016/j.psychsport.2015.06.002

Serpell, B. G., Young, W. B., \& Ford, M. (2011). Are the Perceptual and Decision-Making Components of Agility Trainable? A Preliminary Investigation. Journal of Strength and Conditioning Research, 25(5), 1240-1248. https://doi.org/10.1519/JSC.0b013e3181d682e6

Sheppard, J. M., \& Young, W. B. (2006). Agility literature review: Classifications, training and testing. Journal of Sports Sciences, 24(9), 919-932. https://doi.org/10.1080/026404105 00457109

Stojanovic, M. D., Ostojic, S. M., Calleja-Gonzalez, J., Milosevic, Z., \& Mikic, M. (2012). Correlation Between Explosive Strength, Aerobic Power and Repeated Sprint Ability in Elite Basketball Players. The Journal of Sports Medicine and Physical Fitness, 52, 375-381.

Twist, P. W., \& Benicky, D. (1995). Conditioning Lateral Movements for Multisport Athletes. Practical Strength and Quickness Drills. Strength \& Conditioning, 17, 43-51.

Usgu, G. (2016). Basketbol Oyuncularında Vibrasyon Eşliğindeki Pliometrik Eğitimin Fiziksel Performans Üzerine Etkileri (Yayınlanmamış Doktora Tezi, Hacettepe Üniversitesi Sağlık Bilimleri Enstitüsü, Ankara).

Verstegen, M., \& Marcello, B. (2001). Agility and Coordination in High Performance Sports Conditioning. In B. Foran (Ed.), Champaign: Human Kinetics (pp. 139-165). 


\section{Copyright Disclaimer}

Copyright for this article is retained by the author(s), with first publication rights granted to the journal.

This is an open-access article distributed under the terms and conditions of the Creative Commons Attribution license (http://creativecommons.org/licenses/by/3.0/). 